\title{
HUBUNGAN STATUS GIZI DAN POLA MENSTRUASI DENGAN KEJADIAN ANEMIA PADA REMAJA DI SMAN 2 SINGAPARNA KECAMATAN SINGAPARNA KABUPATEN TASIKMALAYA TAHUN 2018
}

\author{
Tupriliany Danefi, SST.,M.Kes ${ }^{1)}$ \\ tuprilianydanefi07@gmail.com
}

Fenty Agustini, SST.,M.Kes
fentvaqustini86@gmail.com

\section{A. ABSTRAK}

Wanita mempunyai risiko terkena anemia paling tinggi terutama pada remaja putri. Selain itu tingginya angka pernikahan dini/remaja (48\%) menyumbangkan dampak yang tinggi terhadap kejadian anemia yang merupakan implikasi kehamilan dari remaja yang anemia yaitu sebanyak 48 per 1000 kehamilan. Menurut data hasil Riskesdas tahun 2013, prevalensi anemia di Indonesia yaitu $21,7 \%$. Prevalensi anemia pada wanita di Indonesia sebesar 23,9 \% dengan penderita anemia berumur 5-14 tahun sebesar 26,4\% dan 18,4\% penderita berumur 15-24 tahun. Berdasarkan hasil penelitian di wilayah kerja Puskesmas Singaparna tahun 2014 didapatkan data bahwa dari 59 ibu hamil usia kurang dari 20 tahun sebanyak 18,6\% mengalami anemia. Kejadian anemia pada ibu hamil sangat erat kaitannya dengan kejadian anemia pada masa remaja.

Tujuan penelitian ini adalah untuk mengetahui hubungan hubungan status gizi dan pola menstruasi dengan kejadian anemia pada remaja di SMAN 2 Singaparna Kecamatan Singaparna Kabupaten Tasikmalaya tahun 2018. Jenis penelitian yang digunakan dalam penelitian ini adalah penelitian kuantitatif analitik dengan desain cross sectional. Analisa yang digunakan adalah analisa univariat dan bivariat. Populasi dalam penelitian ini adalah seluruh siswi di SMAN 2 Singaparna dengan tekhnik pengambilan sampel menggunakan proportional random sampling sehingga didapatkan sampel sebanyak 77 siswi.

Berdasarkan hasil penelitian didapatkan siswi yang mengalami anemia sebanyak 29,9\% dan yang tidak anemia sebesar 70,1\%. Hasil tabulasi silang mengenai status gizi dengan anemia didapatkan sebanyak 25,7\% siswi dengan status gizi baik mengalami anemia , sedangkan sebanyak 71,4\% siswi dengan status gizi kurang mengalami anemia dengan hasil uji statistik diperoleh $p$ value 0,012 < alpha (0,05). Untuk pola menstruasi dengan kejadian anemia didapatkan sebanyak $28,6 \%$ siswi dengan pola menstruasi normal mengalami anemia, sedangkan sebanyak $37,5 \%$ siswi dengan pola menstruasi tidak normal mengalami anemia dengan hasil uji statistik diperoleh p value 0,597 > alpha $(0,05)$.

Simpulan dalam penelitian ini adalah terdapat hubungan antara status gizi dengan kejadian anemia pada remaja putri dan tidak ada hubungan antara pola menstruasi dengan kejadian anemia pada remaja putri. Saran bagi sekolah Perlu adanya kerjasama dengan fasilitas kesehatan supaya bisa mengadakan penyuluhan tentang gizi remaja di sekolah dan makanan kaya zat besi sehingga remaja memiliki pengetahuan yang baik tentang gizi dan masalah anemia pada remaja putri.

Kata Kunci : Anemia Remaja, status gizi, pola menstruasi 


\section{B. PENDAhuluan}

Masalah gizi sampai saat ini masih menjadi masalah yang penting yang harus diatasi karena Gizi merupakan salah satu faktor penentu untuk mencapai kesehatan yang prima dan optimal. Salah satu masalah gizi yang sering terjadi adalah anemia pada remaja.. Gangguan gizi pada usia remaja yang sering terjadi diantaranya adalah kekurangan energi dan protein, anemia gizi serta defisiensi berbagai macam vitamin. (Khomsan A, 2003)

Pada dasarnya anemia sama halnya dengan masalah Kurang Energi Protein (KEP), Gangguan Akibat Kekurangan Yodium (GAKY), dan Kekurangan Vitamin A (KVA), yaitu suatu keadaan yang salah satu penyebabnya adalah ketidakcukupan beberapa zat gizi yang dikonsumsi seseorang. Ketidakcukupan energi dan protein pada KEP, Yodium pada GAKY, Vitamin A pada KVA, serta tidak adekuatnya asupan beberapa zat gizi seperti zat besi, folat, dan vitamin B12 pada anemia. Kekurangan gizi merupakan penyebab anemia yang mencapai persentasi sekitar $85,5 \%$. Asupan gizi sehari-hari ini dipengaruhi oleh ketersediaan bahan pangan, pola makan dan peningkatan kebutuhan akan zat besi untuk pembentukan sel darah merah yang lazim berlangsung pada masa pertumbuhan. (Arisma, 2010).

Menurut WHO (2008), prevalensi anemia di dunia antara tahun 1993 sampai dengan tahun 2005 sebanyak $24.8 \%$ dari total seluruh penduduk dunia yang hampir 2 milyar penduduk dunia. Indonesia sendiri prevalensi anemia yang didapatkan masih cukup tinggi, dimana data depkes tahun 2009 didapatkan angka kejadian anemia pada remaja mencapai presentasi $33,7 \%$. Menurut data hasil Riskesdas tahun 2013, prevalensi anemia di Indonesia yaitu $21,7 \%$. Prevalensi anemia pada wanita di Indonesia sebesar 23,9\% dengan penderita anemia berumur 5-14 tahun sebesar $26,4 \%$ dan $18,4 \%$ penderita berumur 15-24 tahun. (Kemenkes RI,
2014). Data Survei Kesehatan Rumah Tangga (SKRT) tahun 2012 menyatakan bahwa prevalensi anemia pada balita sebesar $40,5 \%$, ibu hamil sebesar $50,5 \%$, ibu nifas sebesar $45,1 \%$, remaja putri usia 10-18 tahun sebesar 57,1\% dan usia 19- 45 tahun sebesar $39,5 \%$. Wanita mempunyai risiko terkena anemia paling tinggi terutama pada remaja putri. Selain itu tingginya angka pernikahan dini/remaja (48\%) menyumbangkan dampak yang tinggi terhadap kejadian anemia yang merupakan implikasi kehamilan dari remaja yang anemia yaitu sebanyak 48 per 1000 kehamilan. Kehamilan dengan anemia ini akan berdampak pada kematian ibu yang diakibatkan oleh perdarahan pada saat persalinan. (Kemenkes RI, 2013).

Pada anemia yang disebabkan karena kekurangan zat gizi ditandai dengan adanya gangguan dalam sintesis hemoglobin karena kekurangan zat gizi yang berperan dalam pembentukan hemoglobin baik karena kekurangan konsumsi zat besi atau karena gangguan absorbsi. Zat gizi yang bersangkutan adalah besi, protein, piridoksin (vitamin B6) yang mempunyai peran sebagai katalisator dalam sintesis hem di dalam molekul hemoglobin, zat gizi tersebut terutama zat besi $(\mathrm{Fe})$ merupakan salah satu unsur gizi sebagai komponen pembentukan hemoglobin atau membentuk sel darah merah. (Almatsier, 2010)

Anemia merupakan suatu keadaan dimana komponen di dalam darah yaitu hemoglobin $(\mathrm{Hb})$ dalam darah jumlahnya kurang dari kadar normal. Remaja putri memiliki risiko sepuluh kali lebih besar untuk menderita anemia dibandingkan dengan remaja putra. Hal ini dikarenakan remaja putri mengalami mentruasi setiap bulannya dan sedang dalam masa pertumbuhan sehingga membutuhkan asupan zat besi yang lebih banyak. Penentuan anemia juga dapat dilakukan dengan mengukur hematokrit (Ht) yang rata-rata setara dengan tiga kali kadar hemoglobin. Batas kadar Hb remaja putri 
untuk mendiagnosis anemia yaitu apabila kadar Hb kurang 12 gr/dl (Tarwoto, dkk, 2010).

Anemia pada remaja dapat menyebabkan keterlambatan pertumbuhan fisik, gangguan perilaku serta emosional. Hal ini dapat mempengaruhi proses pertumbuhan dan perkembangan sel otak sehingga dapat menimbulkan daya tahan tubuh menurun, mudah lemas dan lapar, konsentrasi belajar terganggu, prestasi belajar menurun serta dapat mengakibatkan produktifitas kerja yang rendah (Sayogo, 2006).

Berdasarkan studi pendahuluan diperoleh data sekunder dari laporan tahunan Program Kesehatan Keluarga Dinas Kesehatan Kabupaten Tasikmalaya, menunjukkan dalam kurun periode waktu 4 tahun terakhir terjadi peningkatan angka kejadian anemia pada remaja putri, yang berkunjung dan terjaring oleh pemeriksaan hemolglobin pada 40 Puskesmas di 39 Kecamatan Kabupaten Tasikmalaya, yaitu:

1) sebanyak 178 remaja putri pada tahun 2012; 2) sebanyak 77 orang pada tahun 2013 ; 3) sebanyak 65 orang pada tahun 2014, serta terjadi peningkatan drastis pada tahun 2015,yaitu sebanyak 155 orang KabupatenTasikmalaya merupakan salah satu kabupaten di Propinsi Jawa Barat yang memerlukan penanggulangan masalah anemia. Berdasarkan hasil survey anemia tahun 2013 diketahui bahwa prevalensi anemia besi pada remaja putri SMP dan SMA adalah 23,2\%, angka ini lebih tinggi dibandingkan dengan angka nasional dan menjadikannya masalah kesehatan sedang.

Berdasarkan hasil penelitian di wilayah kerja Puskesmas Singaparna tahun 2014 didapatkan data bahwa dari 59 ibu hamil usia kurang dari 20 tahun sebanyak 18,6\% mengalami anemia. Kejadian anemia pada ibu hamil sangat erat kaitannya dengan kejadian anemia pada masa remaja. Berdasarkan studi pendahuluan yang dilakukan di SMAN 2 Singaparna dari 10 siswi sebanyak 6 orang siswi yang memiliki pola sarapan yang kurang baik dan 4 orang sering mengalami sakit pada saat menstruasi. Berdasarkan hal tersebut, maka penulis akan melakukan penelitian untuk Hubungan Status Gizi dan Pola Menstruasi dengan Kejadian Anemia pada remaja di SMAN 2 Singaparna Kecamatan Singaparna Kabupaten Tasikmalaya tahun 2018.

\section{METODE PENELITIAN}

Jenis penelitian yang digunakan dalam penelitian ini adalah jenis penelitian kuantitatif analitik dengan desain cross sectional. Populasi dalam penelitian ini adalah seluruh siswi di SMAN 2 Singaparna dengan tekhnik pengambilan sampel menggunakan proportional random sampling sehingga didapatkan sampel sebanyak 77 siswi. Tempat penelitian di SMAN 2 Singaparna Kecamatan Singaparna Kabupaten Tasikmalaya tahun 2018. Teknik pengumpulan data yang digunakan dalam penelitian ini dengan data primer. Analisis yang digunakan dalam penelitian ini adalah analisis univariat untuk menggambarkan distribusi dan frekuensi kejadian anemia pada remaja, status gizi dan pola menstruasi dan analisis bivariat untuk mengetahui hubungan antara status gizi dan pola menstruasi dengan kejadian anemia pada remaja. 


\section{HASIL PENELITIAN}

1. Anemia

Hasil penelitian mengenai anemia pada remaja adalah sebagai berikut:

Gambar 3.1 Distribusi frekuensi anemia pada remaja di SMAN 2 Singaparna Kecamatan Singaparna Kabupaten Tasikmalaya tahun 2018

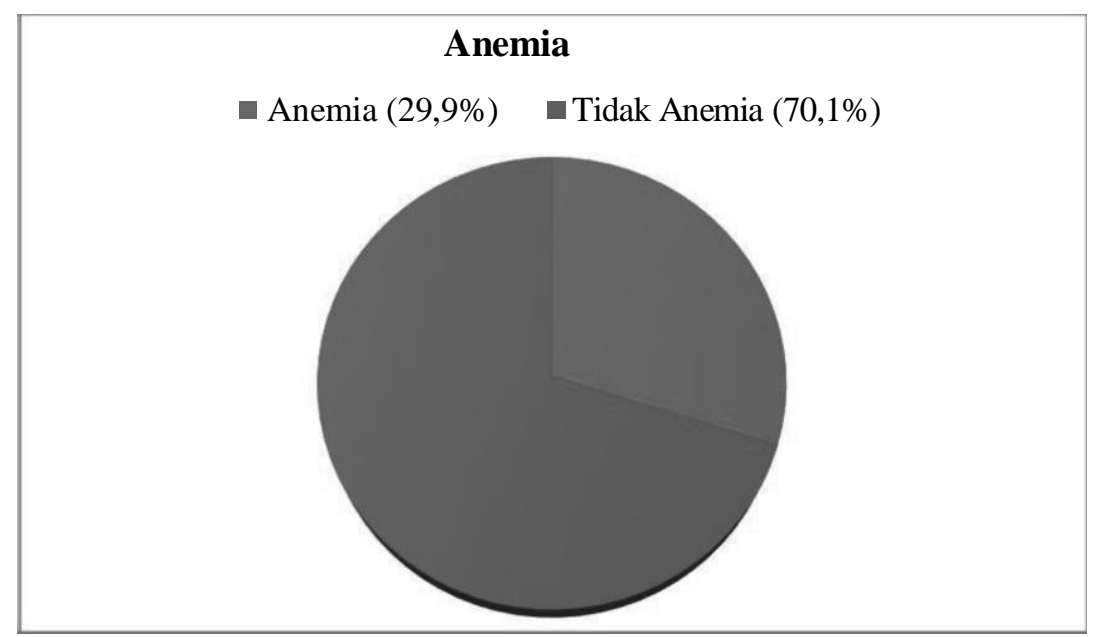

Berdasarkan gambar 3.1 menunjukkan siswi yang mengalami anemia sebesar 29,9\% dan yang tidak mengalami anemia sebesar 70,1\%.

\section{a. Status gizi remaja}

Distribusi responden berdasarkan status gizi pada remaja di SMAN 2 Singaparna

Kecamatan Singaparna Kabupaten Tasikmalaya tahun 2018 adalah sebagai berikut:

Tabel 3.1 Distribusi responden berdasarkan status gizi pada remaja di SMAN 2 Singaparna Kecamatan Singaparna Kabupaten Tasikmalaya tahun 2018

\begin{tabular}{|l|c|c|c|}
\hline No & Status Gizi & Frekuensi & $\begin{array}{c}\text { Persentas } \\
\text { e (\%) }\end{array}$ \\
\hline 1 & Baik & 70 & 90,9 \\
\hline 2 & Kurang & 7 & 9,1 \\
\hline \multicolumn{2}{|c|}{ Jumlah } & 77 & 100 \\
\hline
\end{tabular}

Berdasarkan Tabel 3.1 menunjukkan bahwa status gizi baik sebesar 90,9\% dan yang mengalami status gizi kurang sebesar 9,1\%. Melihat dari data tersebut memang sebagian besar ada pada kategori baik untuk status gizi. Tetapi melihat dari data kebiasaan sarapan sebagian besar siswi jarang untuk sarapan pagi yaitu sebesar 51,9\%, bahkan sampai ada yang tidak pernah sarapan pagi yaitu sebesar 7,8\%.

\section{Pola menstruasi remaja}

Distribusi responden berdasarkan pola menstruasi pada remaja di SMAN 2 Singaparna Kecamatan Singaparna Kabupaten Tasikmalaya tahun 2018 adalah sebagai berikut: 
Tabel 3.2 Distribusi responden berdasarkan pola menstruasi pada remaja di SMAN 2 Singaparna Kecamatan Singaparna Kabupaten Tasikmalaya tahun 2018

\begin{tabular}{|l|c|c|c|}
\hline No & Pola Menstruasi & Frekuensi & $\begin{array}{c}\text { Persentase } \\
(\mathbf{\%})\end{array}$ \\
\hline 1 & Baik & 70 & 90,9 \\
\hline 2 & Kurang & 7 & 9,1 \\
\hline & Jumlah & 77 & 100 \\
\hline
\end{tabular}

Berdasarkan Tabel 3.2 menunjukkan bahwa pola menstruasi normal sebesar 81,8 \% dan yang mengalami pola menstruasi tidak normal sebesar $18,2 \%$. Dari gangguan menstruasi yang dialami remaja diantaranya adalah polimenore, oligomenore, hipermenorea dan dismenorea

\section{Status Gizi dengan Kejadian Anemia remaja}

Hasil penelitian mengenai Status Gizi dengan Kejadian Anemia remaja adalah sebagai berikut:

Tabel 3.3 Cross Tabulation (tabulasi silang) antara Status Gizi dengan Kejadian Anemia pada remaja di SMAN 2 Singaparna Kecamatan Singaparna Kabupaten Tasikmalaya tahun 2018

\begin{tabular}{|c|c|c|c|c|c|c|c|c|}
\hline \multirow{3}{*}{$\begin{array}{c}\text { Pola } \\
\text { Menctruaci }\end{array}$} & \multicolumn{4}{|c|}{ Anemia } & \multirow{2}{*}{\multicolumn{2}{|c|}{ Total }} & \multirow{3}{*}{$P$ value } & \multirow{3}{*}{$\begin{array}{c}\text { OR } \\
(95 \% \mathrm{CI})\end{array}$} \\
\hline & \multicolumn{2}{|c|}{$\mathbf{Y a}$} & \multicolumn{2}{|c|}{ Tidak } & & & & \\
\hline & $\mathbf{F}$ & $\%$ & $\mathbf{F}$ & $\%$ & $\overline{\mathrm{Jml}}$ & $(\%)$ & & \\
\hline Normal & 18 & 28,6 & 45 & 71,4 & 63 & 100 & \multirow{2}{*}{0,597} & 1,389 \\
\hline Tidak Normal & 5 & 37,5 & 9 & 64,3 & 14 & 100 & & $0,409-4,715$ \\
\hline Jumlah & 23 & 29,9 & 54 & 70,1 & 77 & 100 & & \\
\hline
\end{tabular}

Tabel 3.3 memperlihatkan sebanyak $25,7 \%$ siswi dengan status gizi baik mengalami anemia, sedangkan sebanyak $71,4 \%$ siswi dengan status gizi kurang mengalami anemia. Hasil uji statistik diperoleh $p$ value $0,012<$ alpha $(0,05)$ yang berarti ada perbedaan yang signifikan proporsi anemia pada gizi baik dan kurang sehingga dapat disimpulkan ada hubungan antara status gizi dengan kejadian anemia pada siswi. Siswi dengan gizi kurang berpeluang 7 kali mengalami anemia dibandingkan dengan siswi yang status gizinya baik.

\section{Pola Menstruasi dengan Kejadian Anemia remaja}

Hasil penelitian mengenai Pola Menstruasi dengan Kejadian Anemia remaja adalah sebagai berikut: 


\section{Tabel 3.4 Cross Tabulation (tabulasi silang) antara Pola Menstruasi dengan Kejadian Anemia pada remaja di SMAN 2 Singaparna Kecamatan Singaparna Kabupaten Tasikmalaya tahun 2018}

\begin{tabular}{|c|c|c|c|c|c|c|c|c|}
\hline \multirow{3}{*}{$\begin{array}{c}\text { Status } \\
\text { Gizi }\end{array}$} & \multicolumn{4}{|c|}{ Anemia } & \multicolumn{2}{|c|}{ Total } & \multirow{3}{*}{$P$ value } & \multirow{3}{*}{$\begin{array}{c}\text { OR } \\
(95 \% \mathrm{CI})\end{array}$} \\
\hline & \multicolumn{2}{|c|}{ Ya } & \multicolumn{2}{|c|}{ Tidak } & & & & \\
\hline & $\overline{\mathbf{F}}$ & $\%$ & $\overline{\mathbf{F}}$ & $\%$ & $\mathbf{J m l}$ & $(\%)$ & & \\
\hline$\overline{\text { Baik }}$ & $\overline{18}$ & 25,7 & 52 & $\overline{74,3}$ & 70 & 100 & & 7,22 \\
\hline Kurang & 5 & 71,4 & 2 & 28,6 & 7 & 100 & & $1.287-40.543$ \\
\hline Jumlah & 23 & 29,9 & 54 & 70,1 & 77 & 100 & & \\
\hline
\end{tabular}

Tabel 3.4 memperlihatkan sebanyak $28,6 \%$ siswi dengan pola menstruasi normal mengalami anemia , sedangkan sebanyak $37,5 \%$ siswi dengan pola menstruasi tidak normal mengalami anemia. Hasil uji statistik diperoleh p value $0,597>$ alpha $(0,05)$ yang berarti tidak ada perbedaan yang signifikan proporsi anemia pada pola menstruasi normal dan tidak normal, sehingga dapat disimpulkan bahwa tidak ada hubungan antara pola menstruasi dengan kejadian anemia.

\section{E. PEMBAHASAN}

\section{Anemia remaja}

Hasil pengukuran anemia berdasarkan metode sianmethemoglobin menunjukkan bahwa dari 77 responden, yang mempunyai kadar hemoglobin dengan kategori anemia ( $\mathrm{Hb} \geq 12 \mathrm{~g} / \mathrm{dL}$ ) sebesar $29,9 \%$ dan yang tidak mengalami anemia ( $\mathrm{Hb} \leq 12 \mathrm{~g} / \mathrm{dL})$ sebesar 70,1\%.

Berdasarkan Stoltzfus et al. (1999) menyatakan bahwa batasan normal anemia pada wanita > 14 tahun adalah $12 \mathrm{gr} / \mathrm{dl}$. Dari hasil tersebut menunjukkan bahwa sebagian besar siswi tidak mengalami anemia, akan tetapi kejadian anemia pada siswi akan memberikan dampak yang kurang apabila tidak ditangani. Anemia gizi besi adalah anemia yang terjadi akibat kekurangan zat besi dalam darah, artinya konsentrasi hemoglobin dalam darah berkurang karena terganggunya pembentukan sel-sel darah merah akibat kurangnya kadar besi dalam darah. Semakin berat kekurangan zat besi yang terjadi akan semakin berat pula anemia yang diderita (Gibney, 2008).

Anemia merupakan suatu keadaan dimana komponen di dalam darah yaitu hemoglobin $(\mathrm{Hb})$ dalam darah jumlahnya kurang dari kadar normal. Remaja putri memiliki risiko sepuluh kali lebih besar untuk menderita anemia dibandingkan dengan remaja putra. Data Survei Kesehatan Rumah Tangga (SKRT) tahun 2012 menyatakan bahwa prevalensi anemia pada balita sebesar 40,5\%, ibu hamil sebesar $50,5 \%$, ibu nifas sebesar $45,1 \%$, remaja putri usia $10-18$ tahun sebesar $57,1 \%$ dan usia 19 - 45 tahun sebesar 39,5\%, hal tersebut memberikan arti bahwa usia terbanyak yang mengalami anemia ada di usia remaja yaitu $1 \theta \quad 18$ tahun.

Dari hasil penelitian juga dapat dilihat untuk usia minimum siswi yaitu 15 tahun dan usia maksimum siswi yaitu 19 tahun dengan rata rata usia 16 tahun. Artinya usia tersebut masih tergolong remaja pertengahan. Usia remaja merupakan usia 
pertumbuhan anak-anak menuju proses kematangan manusia dewasa. Pada usia remaja, terjadi perubahan pada fisik, biologis, dan psikologis seseorang dan terjadi secara terus-menerus selama usia remaja. Ketidakseimbangan antara asupan dan kebutuhan gizi berakibat pada terjadinya masalah gizi, baik gizi kurang maupun gizi lebih (Briawan, 2013).

Hal ini sesuai dengan teori dari Proverawati (2011:101) yang mengatakan bahwa masa remaja merupakan masa rawan terjadi anemia defisiensi besi pada remaja. Hal ini dikarenakan masa remaja merupakan masa terbanyak penggunaan zat besi untuk pertumbuhan. Masalah gizi yang terjadi pada usia remaja merupakan efek kelanjutan dari masalah gizi yang terjadi saat masih anak-anak. Masalah tersebut antara lain anemia defisiensi besi, kekurangan dan kelebihan berat badan. Kebiasaan makan yang dilakukan semasa remaja akan memberikan dampak terhadap kondisi kesehatan pada fase kehidupan selanjutnya. Remaja putri memerlukan banyak asupan zat besi untuk mengganti zat besi yang hilang bersama darah selama menstruasi berlangsung (Sya'bani \& Sumarmi, 2016).

\section{Hubungan Status Gizi dengan Kejadian Anemia remaja}

Berdasarkan hasil penelitian diperoleh sebanyak $25,7 \%$ siswi dengan status gizi baik mengalami anemia, sedangkan sebanyak $71,4 \%$ siswi dengan status gizi kurang mengalami anemia. Hasil uji statistik diperoleh $\mathrm{p}$ value $0,012<$ alpha $(0,05)$ yang berarti ada perbedaan yang signifikan proporsi anemia pada gizi baik dan kurang sehingga dapat disimpulkan ada hubungan antara status gizi dengan kejadian anemia pada siswi dengan nilai OR sebesar 7,22 yang artinya siswi dengan gizi kurang berpeluang 7 kali mengalami anemia dibandingkan dengan siswi yang status gizinya baik.

Status gizi adalah keadaan seseorang yang diakibatkan oleh konsumsi, penyerapan, dan penggunaan zat gizi dari makanan dalam jangka waktu yang lama. Penilaian status gizi secara langsung dapat dibagi menjadi empat penilaian yaitu antropometri, klinis, biokimia, dan biofisik (Supariasa, 2010). Penilaian yang digunakan untuk menilai status gizi dalam penelitian yang kami lakukan menggunakan antropometri dengan menilai IMT sesuai dengan umur responden. (WHO 2007)

Gizi merupakan kebutuhan yang penting bagi remaja, hal tersebut sesuai dengan pendapat yang dikemukakan oleh Sitiningsih dalam Rumpiati (2010) bahwa gizi atau nutrisi yang baik pada masa remaja memungkinkan kesehatan yang baik, pertumbuhan dan perkembangan yang optimal, gizi yang cukup dan baik juga membentuk kecerdasan otak, jiwa dan kehidupan sosial. Status gizi pada remaja dapat ditingkatkan dengan mengkonsumsi makanan yang memenuhi zat-zat gizi sesuai dengan kebutuhannya.

Berdasarkan data tambahanyang didapatkan bahwa kebiasaan sarapan sebagian besar siswi jarang untuk sarapan pagi yaitu sebesar $51,9 \%$, bahkan sampai ada yang tidak pernah sarapan pagi yaitu sebesar 7,8\%. Hal ini menjadi salah satu faktor yang dapat mempengaruhi status gizi remaja sehingga bisa berdampak terhadap anemia remaja. Sebanyak 71,4\% siswi dengan status gizi kurang mengalami anemia, hal ini disebabkan karena asupan gizi dalam tubuh kurang dan hal ini menyebabkan kebutuhan gizi dalam tubuh tidak terpenuhi terutama kebutuhan gizi seperti zat besi dimana zat besi merupakan salah satu komponen terpenting dalam pembentukan hemoglobin, dengan kurangnya asupan zat besi dalam tubuh akan menyebabkan berkurangnya bahan pembentuk sel darah merah, sehingga sel darah merah tidak dapat melakukan fungsinya dalam mensuplai oksigen yang akan mengakibatkan terjadinya anemia (Sayogo, S, 2006).

Hasil ini sejalan dengan penelitian yang dilakukan oleh Wibowo Tri daris, dkk yang berjudul Hubungan Antara Status 
Gizi dengan Anemia pada Remaja Putri di Sekolah Menengah Pertama Muhammadiyah 3 Semarang. Berdasarkan hasil penelitian didapatkan bahwa responden yang memiliki status gizi baik dengan anemia sebanyak 4 siswi ( $12,9 \%$ ), responden yang memiliki status gizi baik tetapi tidak anemia sebanyak 27 siswi ( $87,1 \%$ ), responden yang memiliki status gizi kurang dengan anemia sebanyak 13 siswi ( $100,0 \%$ ),dan responden yang memiliki status gizi kurang tetapi tidak anemia sebanyak 0 siswi ( $0,0 \%)$. Berdasarkan hasil Uji Chi-Square maka diperoleh nilai significancy 0,000 atau kurang dari 0,05 yang menunjukkan bahwa hubungan antara status gizi dengan anemia bermakna.

\section{Hubungan Pola Menstruasi dengan Kejadian Anemia remaja}

Berdasarkan hasil penelitian diperoleh sebanyak 28,6\% siswi dengan pola menstruasi normal mengalami anemia, sedangkan sebanyak $37,5 \%$ siswi dengan pola menstruasi tidak normal mengalami anemia. Hasil uji statistik diperoleh $\mathrm{p}$ value $0,597>$ alpha $(0,05)$ yang berarti tidak ada perbedaan yang signifikan proporsi anemia pada pola menstruasi normal dan tidak normal, sehingga dapat disimpulkan bahwa tidak ada hubungan antara pola menstruasi dengan kejadian anemia.

Walaupun tidak bermakna tetapi Angka 37,5\% siswi dengan pola menstruasi tidak normal mengalami anemia itu memberikan gambaran bahwa bagi remaja putri yang mengalami pola menstruasi tidak normal memiliki potensi untuk mengalami kejadian anemia. Anemia dapat disebabkan oleh banyak hal, salah satunya adalah kehilangan darah. Remaja putri secara normal akan mengalami kehilangan darah melalui menstruasi setiap bulan. Bersamaan dengan menstruasi akan dikeluarkan sejumlah zat besi yang diperlukan untuk pembentukan hemoglobin. Hal ini merupakan salah satu penyebab prevalensi anemia cukup tinggi pada remaja putri.
Lama menstruasi dapat diukur berdasarkan hari pertama sampai dengan hari terakhir keluar darah. Kehilangan zat besi di atas rata-rata dapat terjadi pada remaja putri dengan pola menstruasi yang lebih banyak dan waktunya lebih panjang (Atikah, 2011).

Uraian diatas menegaskan bahwa Remaja Putri sangat rentan mengalami anemia dimana setiap bulannya mengalami menstruasi baik normal ataupun tidak normal. Dari hasil penelitian didapatkan bahwa 18,2\% siswi mengalami gangguan siklus dan lama menstruasi. Gangguan menstruasi yang dialami remaja diantaranya adalah polimenore, oligomenore, hipermenorea dan dismenorea. Siklus menstruasi dikatakan normal jika jarak antara hari pertama keluarnya darah menstruasi dan hari pertama menstruasi berikutnya terjadi antara selang waktu 21-35 hari (Manuaba, 2009; Wiknjosastro, 2002).

Remaja putri memiliki risiko sepuluh kali lebih besar untuk menderita anemia dibandingkan dengan remaja putra. Hal ini dikarenakan remaja putri mengalami menstruasi setiap bulannya. Baisanya, Remaja putri sangat memperhatikan bentuk tubuh, sehingga banyak remaja putri yang membatasi konsumsi makanan dan banyak juga pantangan terhadap makanan. Sehingga dapat disimpulan, Bila asupan makanan kurang maka cadangan besi yang diserap tubuh juga akan kurang. Keadaan seperti ini dapat mempercepat terjadinya anemia (Agus, 2006). Peneliti berpendapat bahwa remaja putri yang mengalami anemia dapat menimbulkan kemampuan dan konsentrasi belajar menurun, menggangu pertumbuhan sehingga tinggi badan tidak optimal, menurun kemampuan fisik, muka pucat, sehingga diperlukan penanganan yang tepat dalam menghadapi masalah pada remaja yang dikategorikan rentan terhadap anemia.

Melihat data lainnya yang didapat menunjukkan bahwa usia minimal menarche siswi adalah 10 tahun sedangkan 
usia maksimal menarche siswi adalah 16 tahun dengan rata rata usia menarche siswi adalah 12,49 tahun. Hasil penelitian ini menunjukkan bahwa gangguan menstruasi terjadi pada sisiwi dengan usia menarche tertentu, hal ini terjadi karena pada remaja yang mengalami menstruasi lebih awal, maka kondisi emosi remaja tersebut masih belum stabil sehingga mereka lebih mudah stress atau cemas. Dari kondisi tersbut, dapat mempengaruhi siklus hormonal menstruasi yang dapat menimbulkan gangguan pada saat menstruasi.

Upaya yang aman dan efektif untuk mengatasi masalah anemia pada remaja adalah diperlukannya suplementasi zat besi/zinc. Oleh karena itu, adanya suplementasi besi/zinc pada remaja putri diharapkan akan menjadi salah satu cara untuk meningkatkan status gizi dan kesehatan pada remaja putri sehinnga mampu menekan angka kejadian anemia pada remaja putri. Perlu adanya penyuluhan secara menyeluruh dan merata tentang informasi mengenai pentingnya mengkosumsi suplementasi besi/zinc pada remaja setelah mengalami menstruasi.

Responden penelitian merupakan remaja pertengahan dengan kisaran umur 16 tahunan. Pada usia ini remaja membutuhkan banyak zat besi untuk menunjang pertumbuhannya. Kebutuhan zat besi pada remaja baik perempuan maupun lelaki meningkat sejalan dengan cepatnya pertumbuhan dan bertambahnya massa otot dan volume darah. Pada remaja perempuan kebutuhan lebih banyak dengan adanya siklus menstruasi setiap bulannya.

Hasil penelitian ini sejalan dengan penelitian Hatta Muhammad, dkk 2017 tentang "Faktor Yang Berhubungan Dengan Kejadian Anemia Pada Remaja Putri Di Sman 2 Buntumalangka Kabupaten Mamasa Tahun 2017" dimana tidak ada hubungan antara lama menstruasi dengan kejadian anemia dengan $\mathrm{p}$ value 1,000. Tidak adanya hubungan pola menstruasi dengan kejadian anemia diduga karena peneliti hanya menilai lama menstruasinyanya saja sementara jumlah voleme darah yang keluar saat haid tidak dilihat oleh peneliti. Volume darah yang keluar pada saat menstuasi dapat juga mempengaruhi terjadinya anemia. Pada umumnya wanita mengeluarkan darah 30 $40 \mathrm{ml}$ setiap siklus menstruasi antara 21 35 hari dengan lama menstruasi $3 \quad 7$ hari.17 Banyaknya darah yang keluar berpengaruh pada kejadian anemia karena wanita tidak mempunyai persediaan zat besi yang cukup dan absorpsi zat besi yang rendah ke dalam tubuh sehingga tidak dapat menggantikan zat besi yang hilang selama menstruasi. Besarnya zat besi yang hilang pada saat menstruasi tergantung pada banyaknya jumlah darah yang keluar setiap periode menstruasi. Kehilangan besi mengakibatkan cadangan besi semakin menurun, keadaan ini disebut iron depleting state. Apabila kekurangan besi berlanjut terus maka cadangan besi menjadi kosong sama sekali, penyediaan besi untuk eritropoesis berkurang sehingga menimbulkan gangguan pada pembentukan eritrosit tetapi anemia secara klinis belum terjadi, keadaan ini disebut sebagai iron deficient erythropoiesis. Jika jumlah besi menurun terus maka eritropoesis semakin terganggu sehingga kadar hemoglobin mulai menurun, akibatnya timbul anemia hipokromik mikrositer, disebut sebagai iron deficiency anemia. (Bakta IM, 2006)

\section{F. SIMPULAN DAN SARAN}

\section{Simpulan}

Berdasarkan hasil penelitian dapat disimpulkan bahwa :

a. Siswi yang mengalami anemia sebesar $29,9 \%$ dari 77 siswi

b. Ada hubungan antara status gizi dengan kejadian anemia pada remaja putri dimana $\mathrm{p}$ value $0,012<$ alpha $(0,05)$

c. Tidak ada hubungan antara pola menstruasi dengan kejadian anemia 
pada remaja putri dimana $\mathrm{p}$ value

$0,597<$ alpha $(0,05)$

\section{Saran}

a Perlu adanya kerjasama dengan fasilitas kesehatan supaya bisa mengadakan penyuluhan tentang gizi remaja di sekolah dan makanan kaya zat besi sehingga remaja memiliki pengetahuan yang baik tentang gizi dan masalah anemia pada remaja putri.

b. Perlu dilakukannya pemeriksaan kesehatan secara rutin serta menindaklanjuti hasil pemeriksaan dengan memberikan tablet $\mathrm{Fe}$ kepada siswi di sekolah

c. Perlu adanya penyuluhan tentang personal hygiena sehingga siswi tahu akan pentingnya pemiliharaan kebersihan saat mengalami menstruasi setiap bulannya.

\section{G. REFERENSI}

Agus. (2006). Psikologi Remaja: Perkembangan Peserta Didik. Jakarta: PT. Bumi Aksara

Almatsier, S. Prinsip Dasar Ilmu Gizi. Cet VIII. Jakarta: PT Gramedia Pustaka; 2009

Arisma, MB. Gizi Dalam Daur Kehidupan. Ed 2. Jakarta: EGC; 2010

Atikah Proverawati. 2011. Anemia dan Anemia Kehamilan. Nuha Medika, Yogyakarta

Bakta IM, Pendekatan Terhadap Pasien Anemia. In : Sudoyo AW, Bambang Setiyohadi, Idrus Alwi, Marcellus Simadibrata K, Siti Setiati, editors. Buku Ajar Ilmu Penyakit
Dalam. edisi IV, jilid II. Jakarta Pusat: Pusat Penerbitan Ilmu Penyakit Dalam FK UI; 2006.p.622-623.

Briawan, D. (2013). Anemia masalah gizi pada remaja wanita. Jakarta: EGC.

Gibney. 2008. Gizi Kesehatan Masyarakat. Jakarta: ECG.

Khomsan, A. Pangan Dan Gizi untuk Kesehatan. Jakarta: PT Raja Grafindo persada; 2003

Manuaba, IAC. 2009.

Memahami Kesehatan Reproduksi Wanita Edisi 2. Jakarta:EGC

Petunjuk Teknis Penjaringan Kesehatan Anak Sekolah. Direktorat Bina Kesehatan Anak. Dirjen Bina Kesehatan Masyarakat. Depkes RI. 2008

Rumpiati, Ella, $\mathrm{F}$ dan Mustafidah, H, (2010). Hubungan Antara Status Gizi Terhadap Kejadian Anemia Remaja Puteri. Di peroleh pada tanggal 1 Desember 2018 di http://jurnalmediagizipangan.files.wor dpress.com

Sayogo, S. Gizi Remaja Putri. Jakarta: EGC; 2006

Suparisa. (2010). Penilaian Status Gizi. Penerbit Buku Kedokteran EGC, Jakarta.

Sya'bani, I. R. N., \& Sumarmi, S. (2016). Hubungan status gizi dengan kejadian anemia pada santriwati di Pondok Pesantren Darul Ulum Peterongan Jombang. Jurnal Keperawatan Muhammadiyah, 1(1), $7-15$.

Wiknjosastro, H. (2002). Ilmu kandungan. Jakarta: Yayasan Bina Pustaka-Sarwono Prawirohardjo. 